\title{
ABSTRACTS FROM THE ORIGINAL PAPERS.
}

\section{ESSENTIAL OIL OF DOKUDAME.}

\section{By Yeinosuke Shinozaki, Kogakushi.}

[Received March 30, 1921]

By the distillation of the herb, Houttuynia Cordata Thunb., known as lokudame (fresh one required for that purpose), an amount of oil was obtained, thich was of light brown colour and strong somewhat disagreeable odour. his oil has the following characters :-

$\begin{array}{lc}\text { Sp. gr. }\left(15^{\circ}\right) & 0.8744 \\ \text { Ref. index }\left(20^{\circ}\right) & \mathbf{I . 4 6 8 5} \\ \text { Rot. power } & -5^{\circ} \mathrm{O}^{\prime} \\ \text { Acid value } & \mathbf{1 6 . 6 5} \\ \text { Sap. value } & 28.40\end{array}$

The chief constituents of this oil were found by the present author to re (1) methyl-n-nonyl ketone (2) aliphatic terpene (probably myrcene). .he oil was treated with sodium bisulphite, and when the compound thus roduced was treated in the usual manner, a body crystallising at low emperature was liberated which was found to be methyl-n-nonyl ketone; hat was identified by its forming scmicarbazone melting at $122-123^{\circ}$. After he removal of the ketone, the residual oil was repeatedly distilled, the result reing terpene fraction obtained as its chief part. Its psoperties: b. p. jo- $6 \mathrm{I}^{\circ}(\mathrm{I} 4 \mathrm{~mm}), \quad \mathrm{I} 67-\mathrm{I} 68^{\circ}(766 \mathrm{~mm}), \mathrm{sp}$. gr. $\left(15^{\circ}\right) 0.8202 \&$ ref. index $\left.20^{\circ}\right)$ 1.4745. The fraction consists of alphatic terpene (probably myrcene) Ind a small quantity of cylic terpene.

In this oil, a solid acid also is possibly contained. 


\section{ESSENTIAL OIL OF KO-KUSAGI. \\ By Yeinosuke Shinozaki, Kögakushi.}

[Received March, 30, 1921.]

The leaves and twigs of Ko-Kusagi, Oriza japonica, Thunb., yield an amount of a light brown oil, which has a characteristic odour making one somewhat recall that of kuromoji oil. Its characters investigated by the present author are as following :-

$\begin{array}{lc}\text { Sp. gr. }\left(15^{\circ}\right) & 0.8974 \\ \text { Ref. index }\left(20^{\circ}\right) & 1.475^{\circ} \\ \text { Rot. power } & -4^{\circ} 30^{\prime} \\ \text { Acid value } & \text { nil. } \\ \text { Sap. value } & 37.27 \\ \text { Sap. value after acetylation } & 100.3\end{array}$

The oil is soluble in 2 volumes of $80 \%$ alcohol. A small quantity of the oil was fractionated in order to get some idea of its possible constituents. The results are as following:-

\begin{tabular}{lcrcr} 
& \multicolumn{2}{c}{ Fraction } & $\begin{array}{c}\text { Sp. gr. } \\
\left(15^{\circ}\right)\end{array}$ & $\begin{array}{c}\text { Ref. index } \\
\left(20^{\circ}\right)\end{array}$ \\
(1) ca. & $40^{\circ}-60^{\circ}$ & $21.4 \%$ & 0.8760 & 1.4671 \\
$(2)$ & $60^{\circ}-65^{\circ}$ & $14.3 \%$ & 0.8792 & 1.4666 \\
$(3)$ & $65^{\circ}-83^{\circ}$ & $14.3 \%$ & 0.8824 & 1.4665 \\
$(4)$ & $83^{\circ}-95^{\circ}$ & $10.0 \%$ & 0.8892 & 1.4742 \\
$(5)$ & $95^{\circ}-110^{\circ}$ & $14.3 \%$ & 0.9093 & 1.4826 \\
(6) & $110^{\circ}-130^{\circ}$ & $11.3 \%$ & 0.9281 & 1.4959 \\
& residue & $7.0 \%$ & - & -
\end{tabular}

By further experiments the existence of camphene has been proved by its forming isoborneol and the presence of linalool is also possible. Other terpene alcohol and its ester seem to exist in fractions (3), (4) and (5). Sesquiterpene is probably contained in the highest fraction. 


\section{ON THE ELECTROLYTIC OXIDATION OP BENZENE TO QUINONE-}

By Harushige Inouye, Rigakushi, and

Masuzō Shikata, Nogakushi.

[Received April 4, 192r.]

The authors electrolytically oxidised benzene in the sodium salt solution, and obtained good result when the conditions were as follows :-

(1) Cathode solution : benzene Iogrs. \& $4 \% \mathrm{Na}_{2} \mathrm{SO}_{4}$ solution 100 c.c.,. (2) Anode solution: $2 \% \mathrm{H}_{2} \mathrm{SO}_{4}$, (3) Cathode and anode: Pb-plate, (4) Current density : 2-3 amp. per 100 sq. cm., (5) The voltage of the cell : 3-5 volt. (6) The total sum of the electric current : 30 amp. h., \& (7) Temp: under $20^{\circ} \mathrm{C}$.

When anode solution is increased, it automatically returns to the cathode room. When the anode solution is sufficiently agitated, the production of quinone is risen up to $77 \%$ of benzene used. Let Igr. of sodium acetate be added to the anode solution and, for the cathode solution, $5 \% \mathrm{H}_{2} \mathrm{SO}_{4}$ be employed instead of $2 \% \mathrm{H}_{2} \mathrm{SO}_{4}$, then the production of quinone rises to $81.5 \%$.

\section{ON THE THEORY OF THE INFUSIBILITY AND FUSIBILITY OF THE PHENOLIC CONDENSATION PRODUCTS.}

\section{By Sadakichi Satow, Kögakuhakushi,}

[Received April 5, 1921].

The variation of the fusibility and infusibility of the phenolic condensation products, depend mainly upon the combining capacity of formaldehyde with phenol, in other words, upon the number of alcohol groups in the oily condensation products.

In the state of an oily viscous consistency, the condensation products containing no or least number of alcohol groups produce fusibler esin, and also the products containing great number of alcohol groups produce an infusible and insoluble resin.

In a word, infusibility is proportional to the number of alcohol groups in the oily viscous condensation products 


\section{THE OXYGEN INDUSTRY IN JAPAN.}

\section{By Takeo Nakai, Kögakushi.}

[Received April 27, 1921].

The Nihon Sanso Kabushili Kaisha, the pioneer of our oxygen industry, prepared industrial oxygen gas for the first time in 1910 by the Linde process at the Osaki Factory in the suburb of Tokyo. During the great European war, our oxygen industry made a great advance. The present state of oxygen industry in 1920 is as follows :

Number of companies 20

" , factories

27

In addition to this,

$\begin{array}{cc}\text { Number of companies, under contemplation } & 7 \\ \# \quad \text {, factories }, \quad \text { construction } & 8\end{array}$

The Number of the factories divided according to their processes is as follows :

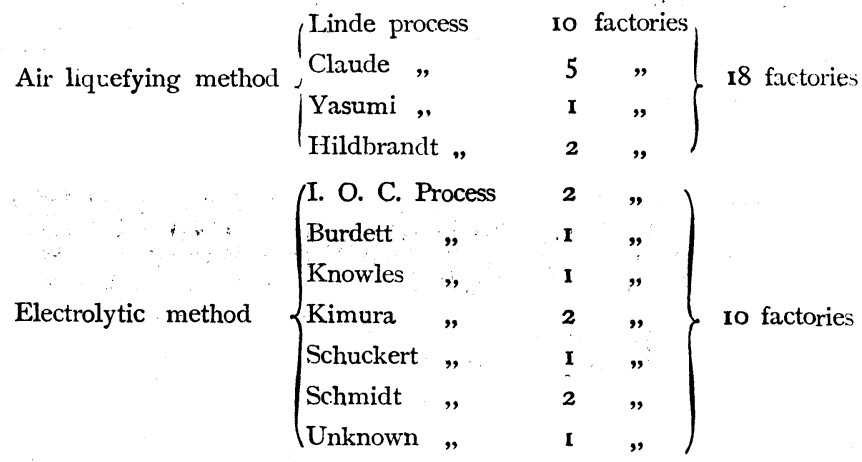

(One factory beside, adopting both processes),

Also, some other data are as follows :

Total investment

$¥ 6.610000$

Number of workmen 381 men.

$\begin{array}{clccc} & \begin{array}{c}\text { Annual } \\ \text { Capacity }\end{array} & \begin{array}{c}\text { Production } \\ \text { in } 1918\end{array} & \begin{array}{c}\text { Production } \\ \text { in 1919 }\end{array} & \text { Quality } \\ \text { Air liquefying method } & 3.484 .800 \mathrm{~cm} . & 816.000 \mathrm{cbm} . & \mathbf{1 . 4 0 5 . 0 0 0} \mathrm{cbm} . & 97 \% \\ \text { Electrolytic method } & \mathbf{1} 531.500 & 520.000 & 714.500 & 99 \% \\ \quad & 5.016 .400 & \mathbf{1} .345 .000 & 2.119 .5 \mathrm{CO} & \end{array}$

